\title{
SATISFACTION OF THE ELDERLY POPULATION ATTENDED IN THE FAMILY HEALTH STRATEGY IN SANTA CRUZ, RIO GRANDE DO NORTE, BRAZIL
}

\author{
Luciane Paula Batista Araújo de Oliveira1, Liz Monique da Fonseca Medeiros², Betina Hörner Schlindwein \\ Meirelles', Sílvia Maria Azevedo dos Santos ${ }^{4}$
}

\footnotetext{
${ }^{1}$ Doctoral student on the Postgraduate Program in Nursing at the Universidade Federal de Santa Catarina (PEN/UFSC), Interinstitutional Modality. Assistant Professor of the Faculty of Health Sciences of Trairi, of the Universidade Federal do Rio Grande do Norte (UFRN). Santa Cruz, Rio Grande do Norte, Brazil. Email: lucianepoliveira@yahoo.com.br

${ }^{2}$ RN, qualified in Nursing at the UFRN. Santa Cruz, Rio Grande do Norte, Brazil. Email: lizmonique@msn.com

${ }^{3}$ Ph.D. in Philosophy of Health and Nursing. Adjunct Professor of the Department of Nursing and of PEN/UFSC, Florianópolis, Santa Catarina, Brazil. Email: betinahsm@ig.com.br

${ }^{4}$ Ph.D. in Education. Professor of the Department of Nursing and of PEN/UFSC. Florianópolis, Santa Catarina, Brazil. Email: silvia.azevedo@ufsc.br
}

\begin{abstract}
This study aimed to identify the satisfaction of the elderly population in relation to the health care received in the Family Health Strategy, in Santa Cruz, in the State of Rio Grande do Norte, Brazil. It is a descriptive quantitative study, with a sample of 101 older adults registered in the municipality's family health system. The data were collected between May and September 2011, using a structured questionnaire, and were analyzed using descriptive statistics. It was observed that $67.3 \%$ of the interviewees were satisfied with the assistance received, and $72.3 \%$ were satisfied with the advice received. In relation to scheduling, waiting times and time spent in the consultations, many were dissatisfied $(62.4 \%, 54.5 \%$ and $70.3 \%$ dissatisfaction, respectively). We conclude that, in spite of the majority of older adults being satisfied with this care, it is necessary to improve the attendance, particularly in the flow of requests for consultations in the units studied.
\end{abstract}

DESCRIPTORS: Aged. Aging. Consumer satisfaction. Primary health care. Nursing.

\section{SATISFAÇÃO DA POPULAÇÃO IDOSA ATENDIDA NA ESTRATÉGIA DE SAÚDE DA FAMÍLIA DE SANTA CRUZ, RIO GRANDE DO NORTE}

RESUMO: Este estudo teve como objetivo identificar a satisfação da população idosa acerca da assistência de saúde recebida na Estratégia de Saúde da Família, em Santa Cruz-RN. Estudo descritivo, de natureza quantitativa, cuja amostra correspondeu a 101 idosos cadastrados na saúde da família do município. Os dados foram coletados entre maio e setembro de 2011, por meio de entrevista estruturada, e analisados através da estatística descritiva. Observou-se que 67,3\% dos entrevistados estavam satisfeitos com a assistência recebida, e 72,3\% estavam satisfeitos com as orientações recebidas. Quanto ao agendamento, tempo de espera e tempo dedicado às consultas, muitos estavam insatisfeitos $(62,4 \%, 54,5 \%$ e 70,3\% de insatisfação, respectivamente). Concluímos que, apesar da maioria dos idosos estar satisfeita com essa assistência, há necessidade de melhoria de atendimento, especialmente no fluxo das demandas de consultas nas unidades estudadas.

DESCRITORES: Idoso. Envelhecimento. Satisfação do usuário. Atenção primária à saúde. Enfermagem.

\section{SATISFACCIÓN DE LA POBLACIÓN DE EDAD AVANZADA ASISTIDA EN LA ESTRATEGIA DE SALUD FAMILIAR DE SANTA CRUZ RIO GRANDE DO NORTE, BRAZIL}

\begin{abstract}
RESUMEN: Este estudio tuvo como objetivo identificar la satisfacción de las personas mayores acerca de la atención sanitaria recibida en la Estrategia Salud de la Familia de Santa Cruz-RN, Brasil. Estudio descriptivo, cuantitativo, cuya muestra correspondió a 101 adultos mayores inscritos en el Estrategia Salud de la Familia Cruz Santa-RN. Los datos fueron recogidos entre mayo y septiembre de 2011, a través de entrevistas estructuradas y analizados a partir de la estadística descriptiva. Se observó que el 67,3\% de los encuestados estaban satisfechos con la atención recibida, y el 72,3\% estaba satisfecho con la orientación recibida. En cuanto a la programación, tiempo de espera y el tiempo invertido en las consultas, muchos no estaban satisfechos (62,4\%,54,5\% y 70,3\% de insatisfacción, respectivamente). Llegamos a la conclusión que, si bien la mayoría de las personas mayores están satisfechos con la ayuda, existe la necesidad de mejora de la atención, sobre todo en la corriente de la demanda de consultas en las unidades.
\end{abstract}

DESCRIPTORES: Anciano. Envejecimiento. Satisfacción de los consumidores. Atención primaria de salud. Enfermería. 


\section{INTRODUCTION}

Population aging has caused important changes in the demographic profile, resulting from the rise in life expectancy and reduction in child mortality. These aspects result from advances in technologies of health care, investment in primary health care and from the development of public policies directed towards the elderly. ${ }^{1}$

In 1940, older adults represented $4.1 \%$ of the total Brazilian population, while in 2010 this figure was $10.8 \%$, which - in absolute values - represents an increase of 1.7 million to 20.6 million in the same period. ${ }^{1-3}$ With the tendency to reduction in population growth rates and the significant changes in the structure of the Brazilian population pyramid, in the sense of its aging, particularly in the advanced ages, it is anticipated that this contingent should achieve, by 2040, the total of 14.1 million, which signifies $6.9 \%$ of the total population, and $24.9 \%$ of the elderly population. ${ }^{2}$

This information causes reflection on the need for programs and public policies for meeting these emerging demands, ensuring quality of life for the elderly population. Such policies must take into account that aging has multiple dimensions, which encompass social, political, cultural and economic issues.

In this context, in 2006, the National Health Policy for the Elderly (PNSPI) was elaborated, the purpose of which was the recovery, maintenance and promotion of older adults' autonomy and independence, directing collective and individual health measures to this end, taking into account the principles and guidelines of the Unified Health System (SUS). ${ }^{4}$

In addition, it stands out that the network for provision of primary services, including the Family Health Strategy (FHS), must be equipped to provide older adults with quality care, with a view to the maintenance and improvement of their quality of life. $^{5}$

In this regard, it becomes relevant to analyze the assistance provided by the FHS team, as well as the functioning of the services provided by the Primary Healthcare Center (UBS, in Portuguese), from the perspective of the elderly service user, using the policy directed to this populational group as a base. Furthermore, it is necessary to characterize the population evaluated, such that future proposals for health actions may be coherent with this group's profile.

The rationale for undertaking this study in the context of the FHS is the need to evaluate the service user in relation to the health services used. It is appropriate to mention the need to undertake studies on the acceptability/satisfaction related to the FHS, which could broaden, for example, the production of knowledge in the area of Nursing. These data could help in the development of new policies, and provide support for managers, professionals and service users such that the care for the older adults may be improved, seeking to contribute to the integrality of the health actions. ${ }^{6}$

Although the FHS prioritizes actions focussing on the promotion, protection and recovery of the health of individuals and the family in all phases of life, what may be observed is that there is as yet no assistance directed at the attendance of the elderly population, as, in the place where the present study was undertaken, this population is attended only in consultations directed towards the people registered on the Hiperdia system. Given this fact, this study sought to respond to the following question: How satisfied is the elderly population attended in the FHS of the municipality of Santa Cruz, in the State of Rio Grande do Norte?

The study aimed to identify the satisfaction of the elderly population regarding the healthcare received in the Family Health Strategy, in the municipality of Santa Cruz, RN.

\section{METHODS}

This is a quantitative study of the descriptive type, undertaken in the municipality of Santa Cruz-RN, where the mean life expectancy is 71.1 years old. ${ }^{7}$ In this locality, 4,725 persons are in the age range aged over 60 years old, representing $15.1 \%$ of the total population. ${ }^{8}$

A large part of this population is attended by the 12 teams of the centers covered by the FHS, of which two are located in the rural zone and the remaining 10 in the urban zone. The participants in this study were elderly (persons aged 60 years old or over), registered in the FHS, and attended in five FHS centers located in the urban zone of the municipality of Santa Cruz-RN.

The elderly population registered in the FHS of the urban zone of the municipality of Santa Cruz corresponds to a total of 3,611 persons. ${ }^{7}$ Taking this information into account, the sample was obtained using the Epi-Info 6.0 software, being calculated based on a previously-undertaken study, which observed that $77.9 \%$ of the service users were satisfied with the advice provided for following in their homes. ${ }^{6}$ 
Thus, with the confidence interval of $95 \%$, a sample was obtained of 101 participants, which was stratified according to the five health centers existing in the urban zone. Both men and women were interviewed, respecting the same proportion. In this way, the subjects invited to participate in the research were those who sought attendance in these centers, at the time that the researcher was present, with the sample thus being characterized as a non-random convenience sample.

The study included older adults who were competent in terms of cognition and verbal communication, and who received any form of attendance in the FHS. The evaluation of the mental state was made subjectively based on the observation of these older adults and on their participation in the context of the health center. Those who did not have the cognitive conditions to respond to the research instrument were excluded.

The project was referred to the Universidade Federal do Rio Grande do Norte Research Ethics Committee (REC), following authorization from the above-mentioned Family Health Centers (FHC) and from the Municipal Health Department, and respected the guidelines of the National Health Council's Resolution 196/1996, which deals with research with human beings. ${ }^{9}$ Data collection was undertaken following the REC's approval (Opinion n. 157/2011) and the signing of the Terms Free and Informed Consent by the participants.

Data collection took place between the months of May and November 2011, through interviews which were held individually in the FHC, avoiding clashes with the time of the consultations in the centers. The interviews took place in an appropriate place and respecting the service users' willingness to respond to the questionnaires, which were filled out by the interviewer.

In order to assess the satisfaction of the older adults in the FHS, a structured interview script was used, based in Donabedian's dimensions of structure-process-outcome, which was elaborated and validated by previous studies. ${ }^{6}$ In this study, the following were considered as independent variables: the socio-demographic aspects, the length of time that the older adult had attended the center, accessibility, use of other services, participation in programs, referral and counter-referral, undertaking tests, specialist staff, giving opinions regarding the services, obtaining the appointment card for attendance, and waiting time to be attended. The service user's satisfaction with the attendance was considered a dependent variable.
The dimension of 'structure' was evaluated taking into account aspects such as how long the service user had been attending the FHS, accessibility to the FHC, and their use of other services besides the FHC. The evaluation of the dimension 'process' included the FHS programs in which the service users participated, their participation in lectures, the referrals, and the complementary tests undertaken. The third and last stage - evaluation of the dimension 'outcome' - included aspects related to: the service users' link with the team; the users' participation and opinion regarding community participation; the satisfaction with the information received, waiting times and arrangement of consultations; and to the satisfaction with how the user is received by the team. ${ }^{6}$

Some authors argue that any discussion relating to quality involves, implicitly or explicitly, the notion of the evaluation. ${ }^{10}$ Depending on the framework used, three dimensions must be considered for evaluating the quality of the health services: the technical performance, that is, application of the knowledge and the technology in health, such as to maximize the benefits and reduce the risks; the interpersonal relationships: the relationship with the patient; and the amenities: the comfort and aesthetics of the installations and equipment in the place where the services shall be provided. ${ }^{11}$

The analysis was undertaken using descriptive statistics, with the support of Excel 2007 and the Statistical Package for the Social Sciences (SPSS) 17.0 software, with the results being presented in the form of graphs and frequency tables. Measurements of asymmetry such as standard deviation and variance were only considered in the variable referent to the scores attributed to the professionals on the part of the service users.

\section{RESULTS}

The older adults who participated in this study had a mean age of 72.4 years old, distributed in accordance with the following age ranges: 60 to 65 years old (20.8\%), 66 to 70 years old $(24.8 \%), 71$ to 75 years old $(17.8 \%), 76$ to 80 years old $(9.9 \%)$, 81 to 85 years old $(15.8 \%), 86$ to 90 years old $(7.9 \%)$ and over 90 years old (3.0). We emphasize that the largest group was in the age range between 65 and 70 years old $(24.8 \%)$; however, if we add the values of the age ranges from 80 years old and over, these make up an accumulated frequency of $26.7 \%$.

In the present study, the percentage of $50 \%$ 
women and 50\% men was not considered a significant result, bearing in mind that, initially, it was stipulated that the interviews would respect the same proportion between the male and female sexes.

Regarding the level of education, we found that the majority had not finished junior high school ( $52.4 \%$ ), followed by $40.6 \%$ who were illiterate, $5 \%$ with junior high school complete, $2 \%$ with senior high school complete, and no participants in the category of senior high school incomplete. In relation to marital status, $64.4 \%$ of the interviewees were married or lived with a partner, while $20.8 \%$ of the older adults who participated in the study were widowed, $7.9 \%$ single, and $6.9 \%$ divorced.

In relation to family income, $4 \%$ had an income below one minimum salary (MS), $79.2 \%$ of the older adults receive between one and three MS; $12.8 \%$, between three and five MS; $1.0 \%$, from 5 to $7 \mathrm{MS}$; and 3\% had an income above seven MS. The main source of income was the retirement pension (90\%); $2 \%$ had income from employment; $2 \%$, from social programs; $1 \%$, from the spouse; while 3\% mentioned other, unspecified, sources of income.

It was also ascertained that $45.5 \%$ of the older adults shared their home with another three or four persons, followed by families with one and two members $(34.7 \%)$, five and six members $(15.8 \%)$, seven and eight members (3\%), and only one percent lived with another nine or 10 family members. This finding evidences the possibility of other members of the family group depending financially on the older adult.

\section{Evaluation of the structure}

It was ascertained that $95 \%$ of the participants had been using the FHC services for more than two years; $3 \%$, for between one and two years; and 2\%, for between seven and 12 months. Regarding characteristics of accessibility, the majority of the interviewees spent between zero and 15 minutes traveling from their residence to the health center $(64.4 \%)$ and, in general, considered the route traveled to be appropriate (42.6\%).

In relation to the use of other health services, $45.3 \%$ used a regional hospital located in the municipality studied, $23.4 \%$ sought attendance in the institutions in the state capital, $27 \%$ used other services and $13 \%$ did not seek any other service for attendance; the answers could include more than one alternative.

\section{Evaluation of the process}

Thus, in relation to participation in health programs in the FHS, $69.3 \%$ of the participants were attended by the "Hiperdia program", 28.7\% participated in other programs (women's health, collection of cytological tests) and only $2 \%$ of the interviewees did not participate in any of the programs.

Another important data in the evaluation of the process is the service users' participation in health education activities. In the present study, $37 \%$ of the older adults confirmed that they participated in lectures in the health center, while $63 \%$ did not participate. Table 1 shows the actions of referral and counter-referral, that is, referrals to specialist doctors, hospital attendance, or the requesting of tests on the part of the FHS.

Table 1 - Distribution of the older adults by referral to specialist services. Santa Cruz-RN, 2011

\begin{tabular}{lccc}
\hline Actions of referral and counter-referral & $\mathbf{n}$ & $\%$ \\
\hline Was referred by the FHS to spe- & Yes & 62 & 61.4 \\
cialist doctors & No & 39 & 38.6 \\
Was referred by the FHS for hos- & Yes & 36 & 35.6 \\
pital attendance & No & 65 & 64.4 \\
$\begin{array}{l}\text { Undertook some test requested } \\
\text { by the doctor/nurse in the FHS }\end{array}$ & No & 90 & 89.1 \\
\hline
\end{tabular}

Among those who were referred by the FHS to undertake attendance in specialized services, 34 older adults $(54.83 \%)$ were male, and $28(45.17 \%)$ were female. In relation to referrals for attendance in hospital institutions, 21 were male $(58.33 \%)$ and 15 were female $(41.67 \%)$. Regarding the undertaking of complementary tests requested by FHS professionals, it was observed that the distribution was the same, that is, of the 90 participants who confirmed that they had undertaken such tests, $50 \%$ were male and $50 \%$ female.

\section{Evaluation of the outcome}

When questioned whether they knew the FHS professionals or not, the member of the team mentioned most was the Community Health Worker (CHW), followed by the nurse, doctor, auxiliary nurse and, lastly, the dentist (Table 2). 
Table 2 - Distribution of the older adults by knowledge of the members of the Family Health Strategy team. Primary Healthcare Centers. Santa Cruz-RN, 2011

\begin{tabular}{|c|c|c|c|}
\hline $\begin{array}{l}\text { Link with the professionals } \\
\text { of the FHS* }\end{array}$ & & $\mathbf{n}$ & $\%$ \\
\hline \multirow{2}{*}{$\begin{array}{l}\text { Knows the doctor who attended } \\
\text { him/her in the FHS }\end{array}$} & No & 19 & 18.8 \\
\hline & Yes & 82 & 81.2 \\
\hline \multirow{2}{*}{$\begin{array}{l}\text { Knows the nurse who attends } \\
\text { him/her in the FHS }\end{array}$} & No & 18 & 17.8 \\
\hline & Yes & 83 & 82.2 \\
\hline \multirow{2}{*}{$\begin{array}{l}\text { Knows the dentist who attends } \\
\text { him/her in the FHS }\end{array}$} & No & 68 & 67.3 \\
\hline & Yes & 33 & 32.7 \\
\hline \multirow{2}{*}{ Knows the auxiliary nurse } & No & 23 & 22.8 \\
\hline & Yes & 78 & 77.2 \\
\hline \multirow{2}{*}{$\begin{array}{l}\text { Knows the Community Health } \\
\text { Worker }\end{array}$} & No & 8 & 7.9 \\
\hline & Yes & 93 & 92.1 \\
\hline
\end{tabular}

Another point discussed in the evaluation of the process is the importance of knowing the service user's opinion on the assistance received. In relation to this aspect, $83.2 \%$ of the interviewees said that they had never given their opinion on the activities undertaken in the FHS, and only $16.8 \%$ had already had the opportunity to express it.

When questioned as to whether they would like to participate in the process of evaluating the activities undertaken in the center, $63.4 \%$ responded that they agreed to participate, and $36.6 \%$ responded that they were totally in agreement. None of the participants responded that they did not agree or totally disagreed.

In relation to satisfaction regarding the information received on their illness, $74.3 \%$ said that they were satisfied, $5.9 \%$ responded that they were not, $17.8 \%$ responded that they were more or less satisfied, and $2 \%$ did not answer. When they spoke specifically on information about their drug treatment, $74.2 \%$ responded that they were satisfied, $3 \%$ were not satisfied, $20.8 \%$ responded that they were more or less satisfied, and $2 \%$ did not answer.

Regarding satisfaction in relation to the information or advice provided by the professional, $72.2 \%$ of the interviewees said that they were satisfied, $3 \%$ responded that they were not, $22.8 \%$ responded that they were more or less satisfied, and $2 \%$ did not answer.
Regarding satisfaction with how the appointment card for the consultation in the center was obtained, $62.3 \%$ of the older adults stated that they were not satisfied, $21.8 \%$ responded that they were, $14.9 \%$ responded that they were more or less satisfied, and $1 \%$ did not provide an opinion. In relation to the waiting time for attendance in the centers, $54.4 \%$ said that they were not satisfied, while $13.9 \%$ showed satisfaction, $30.7 \%$ responded that they were more or less satisfied, and $1 \%$ did not answer.

As well as not being satisfied with the waiting time for attendance, many older adults were dissatisfied with the time spent in the consultation (70.3\%), followed by $23 \%$ who were partially satisfied, and only $5 \%$ who answered that they were satisfied with the length of the attendance; while in $90 \%$ of cases, they argue that the waiting time to be seen in the unit should be below 30 minutes. ${ }^{12}$

Another aspect evaluated by the instrument is the attribution of a score varying from 0 to 10 points by the service user for evaluating the professional who attends him or her. In this study, the highest mean was attributed to the dentist (9.6\%), the professional who was previously indicated as that least known by the service users, a relationship which was not within the scope of this study. The CHW, on the other hand, received, on average, a score of 9.5; both the nurse and the doctor received a mean of 9.3; the center's receptionist obtained a mean of 9.2; and the mean for the auxiliary nurse or nursing technician was 8.9.

One fairly significant data in the analysis of these scores is the fact that the lowest mean (8.9) was attributed to the auxiliary nurse/nursing technician. Due to the organization of the attendance in the FHS, these professionals are more vulnerable to criticism, as, in the context of the municipality where the study was undertaken, it is generally they who are responsible for handing over appointment cards, scheduling consultations, handing over medications and organizing spontaneous demand, which could be said to correspond more with the role of the receptionist.

Finally, Figure 1 shows the study participants' satisfaction with the health assistance provided by the FHS team, in which $67.3 \%$ responded that "yes", they were satisfied with the service, followed by $26.7 \%$ who answered that they were "more or less" satisfied, $4.0 \%$ who showed dissatisfaction, and $2.0 \%$ who did not answer the question. 


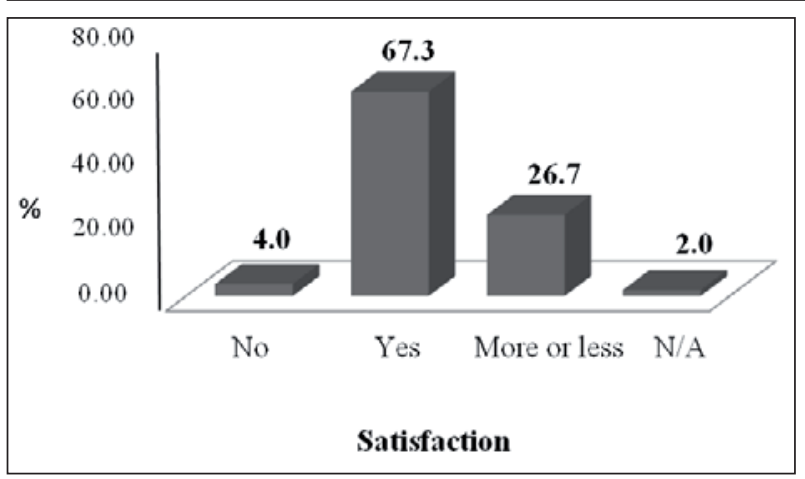

Figure 1 - Distribution of the older adults by satisfaction with the health care provided by the Family Health Strategy team. Primary Healthcare Centers, Santa Cruz-RN, 2011

\section{DISCUSSION}

In the present study, the mean age accompanied the Brazilian tendency, where the proportion of the population aged 80 years old or over is increasing at an accelerated speed, this being the population segment which grows most. From 170,700 persons in 1940, the "oldest" contingent reached 2.9 million in 2010 , which represents $14.2 \%$ of the elderly population in 2010 , and $1.5 \%$ of the total population. ${ }^{2}$ Studies report that this age range represents a delicate point in the elderly population, as, the more advanced the age, the greater the risk of falling ill and presenting a higher degree of dependence. ${ }^{13}$

In this study, the older adults showed satisfaction in relation to the time spent for traveling to the health center, and a large proportion had been using this service for over two years. Access is an obligatory requisite for primary care to become a gateway to the health system, it being necessary to eliminate financial, geographical, organizational and cultural barriers. ${ }^{12}$ In other studies, it was seen that the expansion of the family health teams was used for broadening the population's access to the health services, and for organizing the gateway to the system, although there are still problems in this regard. ${ }^{14}$

The service users seek the health service in situations of acute suffering and, when the primary care center does not respond to their needs, resort to the Emergency Room services, taking up their time with demands considered to be "simple", which could have been resolved at the level of primary care. ${ }^{15}$ In the local context, the people tend to seek emergency attendance in a small hospital* located in the municipality of
Santa Cruz-RN, which is not yet organized to assist those individuals who need care of a greater level of complexity, and which also attends the demand from residents in neighboring municipalities.

It is worth noting that, although the majority of the interviewees were registered on the "Hiperdia program", this program is not exclusively for older adults. The "Hiperdia program" was created through Ministerial Ordinance N. 16/GM, of $3^{\text {rd }}$ January 2002, as the Plan for the Reorganization of Care for Arterial Hypertension and Diabetes Mellitus, with the objective of establishing goals and guidelines broadening actions of prevention, diagnosis, treatment and control of these illnesses, through reorganizing the healthcare work of the centers in the SUS primary care network centers. ${ }^{15}$

It is important to emphasize that the illnesses mentioned in this program are considered Chronic Noncommunicable Diseases (NCD), which tend to be found more commonly in adults who enter old age with these conditions, which, partly, explains the large number of people aged over 60 years old attended by this program. It was observed that the older adults who were not registered on the "Hiperdia program", and who answered that they participated in another program, or were actually receiving attendance from consultations which were open to spontaneous demand, or were in the programs for attention to women's health.

In this regard, it seems that it is necessary to better organize the attendance in the programs provided in primary care, bearing in mind that some of the consequences of the spontaneous demand can include the forming of lines of people waiting to be attended, service users' dissatisfaction with the waiting times, the overburdening of the professionals, the non-prioritization of some consultations, and low capacity to resolve problems.

In accordance with this idea, in a study on spontaneous demand undertaken in a FHC in the state of Minas Gerais, it was observed that receiving a large clientele in the centers has been an arduous and complex task, as a guarantee of the quality of the attendance for the service users, on the majority of occasions, is not achieved. ${ }^{16}$

On the other hand, the Ministry of Health stipulates that the FHS team must not wait for the population to arrive at the health services prior to intervening, but must interact with the population preventively, constituting an instrument for reorganizing the demand. ${ }^{17-18}$ In this context, it is

* A 'small' hospital in Brazil is one with up to 50 beds. Translator's note. 
evidenced that one needs a plan of action which attends emerging needs, so as to reorganize the actions provided to the elderly population.

Education and health are among the principle characteristics of the FHS; educational processes must be undertaken through groups geared towards the recovery of self-esteem, the exchanging of experiences, and mutual support, as well as the improvement of self-care, which is something fundamental in ensuring the independence of the older adult. ${ }^{18}$

This group needs a specific approach, respecting its specific characteristics, with the aim of ensuring the best understanding of the service users, and improving the health care, it being important also to consider the older adults' level of education, so as to select the most appropriate strategies for working with the health education actions.

In relation to referrals to specialist services, it is believed that the resolutive capacity and the continuity of the care depend not only on the relationship established between the service user and the health professionals, but, above all, on the use of primary care as a gateway to the SUS. ${ }^{12}$ Nevertheless, the results achieved in this study do not allow us to make inferences regarding the resolutive capacity of primary care, or to identify the reasons for the referrals, which indicates the need for future studies able to respond to these gaps.

Access to requesting and undertaking laboratory tests seems not to be a problem in the centers studied, as the collection of samples tends to be undertaken in the center itself and these are sent for analysis in the laboratory of the regional hospital located in the municipality. As for the other tests requested, as well as some referrals to specialist doctors, it was observed that, for some participants, there is a large delay both in arranging the same, and in delivering the results.

In this study, the professionals who were remembered most by the older adults were the $\mathrm{CHW}$, followed by the nurses, doctors, auxiliary nurses/nursing technicians, and dentists. Thus, it is believed that - as they are close to the community and the health team - the CHW can facilitate the creation of links. However, in the attempt to give positive results to the population's demands, these often end up taking on activities which go beyond the actions set out in the norms of the Ministry of Health, and thus end up by breaking the organization of the work. ${ }^{18}$

Regarding the attention received by the nurse, the results corroborate a previous study, in which it was observed that some older adults seem not to understand the functions of this member of the team, as they tend to represent her as the professional who only checks blood pressure or who takes the place of the doctor when this cannot undertake the visit. Thus, on most occasions, they confuse the nurse with the nursing technician or with the $\mathrm{CHW}$. It is understood that both the nurse and the other professionals of the FHS need to undertake more actions in patients' homes, principally with attendance which is more focused on the older adult. ${ }^{19}$

In this study, the other professionals obtained lower percentages, which may be attributed to the fact that the majority of them had not worked for very long in these health centers, bearing in mind that many were contracted in the last public examination for filling vacancies for the FHS of the municipality of Santa Cruz, in the beginning of 2010 .

In relation to the fact of being able to express one's personal opinion about the functioning of the health services, the present study's findings showed a discrepancy between thinking and acting, as although the majority of the older adults agreed that they should evaluate the activities undertaken in the FHS, few mentioned having taken this opportunity. This fact may be attributed to the historical exclusion of these people from decisionmaking, causing many service users to feel afraid of giving their opinion and being misunderstood, hindering awareness in relation to the importance of their participation. ${ }^{20}$

The evaluations of satisfaction of the users of the public services can act as an instrument for enabling the service users to be heard, creating opportunities for expression in which the service users can monitor and control the activities of the public health services. ${ }^{21}$

Another aspect analyzed was the provision of information and advice about care to be undertaken in the home by the service user herself and/ or her family members, and other actions related to health education. Work in health with the elderly population depends on the training and involvement of the health professionals in the development of activities which seek to prevent losses of the elderly population's functional capacity, as well as to recover and maintain it, and to control factors which interfere in this population's health. ${ }^{22}$

The older adults interviewed expressed dissatisfaction regarding how consultations are scheduled, the waiting time in the health center, and the duration of each consultation. In the context studied, the teams tend to reserve some specific days 
of the week for scheduling consultations with the nurses, doctors and dentists, with approximately 10 to 20 spaces being made available per period allocated for consultations. In daily practice, it is common to meet service users who complain about the time spent in the waiting rooms, and that the duration of each consultation does not always seem to be proportional to the time spent waiting, which may be a factor related to the service user's dissatisfaction in relation to the services offered in the health center. However, as the object of this study was not to establish relationships between the causes of dissatisfaction with these aspects, this approach is suggested for future studies.

In studies undertaken in other contexts, the service users also expressed a high degree of satisfaction in relation to their relationship with the professionals regarding respect, consideration, listening, understanding, reception and kindness on the part of the team. ${ }^{23}$

In this study, the participants' dissatisfaction with some situations experienced in the FHS is alarming; however, when one refers to the assistance provided by the professionals, the responses had a positive tendency, in which the mean score attributed by the participants was at least 8.9 (in this case, the auxiliary nurse/nursing technician).

The recent National Research for Sample of Domiciles (NRSD) debunk the idea of the SUS service users' dissatisfaction, bearing in mind that, in evaluating the attendance received, a significant number of elderly Brazilians approved of the service provided, and only $2.9 \%$, in the year of 1998 , and $3 \%$, in 2003, found its functioning bad or very bad. ${ }^{24}$

\section{FINAL CONSIDERATIONS}

It is believed that the undertaking of studies on the satisfaction of the service users in a health service can be an important instrument in the search for better conditions of attendance to the health needs of the older adult in primary care.

Generally speaking, the elderly population studied reported satisfaction in relation to the care received regarding information on any illness diagnosed, drug treatment, and guidance provided for undertaking health care in the home, and attributed satisfactory scores for all the professionals of the FHS team. However, many older adults mentioned dissatisfaction with the scheduling of consultations, as well as the short period of time they spend in these, which tend to take place after a long time spent waiting in line.
In the present study, many older adults stated that they had never given an opinion on the activities undertaken in the FHS, which places even greater emphasis on the importance of investigating the opinion of the older adult in relation to the care received in this service, which is configured as a preferential gateway to the SUS for this clientele. Care for the older adult continues to be a challenge for managers and professionals, as it involves a group of persons who experience situations specific to this phase of life, which, when not treated, can culminate in loss of independence and autonomy.

The FHS is a privileged space for comprehensive care to the health of the older adult, as its proximity to the community and to home care make it possible to work in a contextualized way in the reality experienced by the older adult within the family. As a result, one of the major challenges for the workers in the FHS is the need to review their practice, in the light of a new health context, in which the chronic conditions become more frequent and require continuous and comprehensive care, it being indispensable to rethink the work processes, as well as to adopt methodologies, instruments and knowledge which meet the current demand.

The study also indicated that the professionals most recognized by the older adults are the CHW and the nurses, and in this regard, it is believed that it is necessary to study these professionals' profile and work, including - among other aspects - the relationships which these construct with the older adults, family members and the community.

Furthermore, it is observed that the space for attending the elderly service users in family health centers tends to be the "Hiperdia program" consultations, which, in the majority of cases, are undertaken by the nurse. For this reason, we emphasize the importance of the work of the nurse in the FHS, bearing in mind that this professional must be able to identify the social and health needs of the population under their responsibility, as well as to be able to intervene in the health-illness process of the individuals, family and collectivity. Thus, the recognition on the part of the managers of the need to encourage and promote the training of the professionals involved in the care for the older adult becomes essential.

On the other hand, the elderly population must also be informed about its rights, and encouraged to express its wishes and needs, which can be a part of broadening its participation in the functioning of the services, with a view to establishing care which values the satisfaction of the elderly service user. 


\section{REFERENCES}

1. Camarano AM. Envelhecimento da população brasileira: continuação de uma tendência. Recife (PE): FundaçãoJoaquim Nabuco(Fundaj); 2011 [acesso 2011 nov 10] Disponível em: http:/ /www.coletiva.org/ site/index.php?option $=$ com_k2\&view $=$ item\&id $=5$ 8:envelhecimento-da-popula \% C3\% A7\% C3\% A3obrasileira-continua \%C3\%A7\%C3\%A3o-de-uma-te nd $\%$ C3\%AAncia\&tmpl=component\&print $=1$

2. Camarano AM, Kanso S. Perspectivas de Crescimento para a População Brasileira: velhos e novos resultados. Rio de Janeiro (RJ): IPEA; 2009.

3. Instituto Brasileiro de Geografia e Estatística [página na internet]. Rio de Janeiro (RJ): IBGE; 2009. Pesquisa Nacional por Amostra de Domicílios 2009 [atualizado em 2012 Mar 04; acesso 2012 Mar 24]. Disponível em: http://www.ibge.gov.br/home/estatistica/ populacao/trabalhoerendimento/pnad2009/

4. Ministério da Saúde (BR), Secretaria de Atenção à Saúde. Portaria n. 2.528 de 19 de outubro de 2006. Dispõe sobre a Política Nacional de Saúde da Pessoa Idosa. Brasília (DF): MS; 2006.

5. Ministério da Saúde (BR), Departamento de Atenção Básica. Guia prático do Programa de Saúde da Família. Brasília (DF): MS; 2001.

6. Oliveira MM. Avaliação da aceitabilidade do usuário/família sobre a Estratégia Saúde da Família [tese]. Ribeirão Preto (SP): USP/ Programa de PósGraduação em Enfermagem em Saúde Pública; 2008.

7. Ministério da Saúde (BR). Informações de Saúde. Sistema de Informação de Atenção Básica-SIAB. Brasília (DF): MS; 2010.

8. Instituto Brasileiro de Geografia e Estatística [página na internet]. Indicadores Sociodemográficos. Prospectivos para o Brasil 1991-2003. Rio de Janeiro (RJ): IBGE; 2006 [acesso 2010Set 7]. Disponível em: http:// www.ibge.gov.br/home/estatistica/populacao/ projecao_da_populacao/publicacao_UNFPA.pdf

9. Ministério da Saúde (BR), Conselho Nacional de Saúde, Comissão Nacional de Ética em Pesquisa. Resolução n. 196 de 10 de outubro de 1996: diretrizes e normas regulamentadoras de pesquisa envolvendo seres humanos. Brasília (DF): MS; 1996.

10. Donabedian A. The seven pillars of quality. Arch Pathol Lab Méd. 1990 Nov; 114(1):1115-8.

11. Starfield B. Atenção primária: equilíbrio entre necessidades de saúde, serviços e tecnologia. Brasília (DF): Unesco/MS; 2004.

12. Almeida PF, Fausto MCR, Giovanella L. Fortalecimento da atenção primária à saúde: estratégia para potencializar a coordenação dos cuidados. Rev Panam Salud Publ. 2011 Fev; 29(2):84-95.

13. Marin MJS, Angerami ELS. Caracterização de um grupo de idosas hospitalizadas e seus cuidadores visando o cuidado pós-alta hospitalar. Rev Esc Enferm. USP. 2002 Mar; 36(1):33-41.

14. Cecílio LCO. As necessidades de saúde como conceito estruturante na luta pela integralidade e equidade na atenção à saúde. In: Pinheiro R, Mattos RA. Os sentidos da integralidade na atenção e no cuidado à saúde. Rio de Janeiro (RJ): Abrasco; 2006: 115-28.

15. Ministério da Saúde (BR). Plano de reorganização da atenção à hipertensão arterial e ao diabetes mellitus. Manual de hipertensão arterial e diabetes mellitus. Brasília (DF): MS; 2002.

16. Esperança AC, Cavalcante RB, Marcolino C. Estudo da demanda espontânea em uma unidade de saúde da família de uma cidade de médio porte do interior de Minas Gerais. Rev Mineira Enferm. 2006 Jan-Mar; 10(1):30-6.

17. Ministério da Saúde (BR). Pesquisa Nacional de Avaliação da Satisfação dos Usuários do SUS. Brasília (DF): MS; 2006. [acesso 2010 Out 14]. Disponível em: http://portal.saude.gov.br/portal/arquivos/pdf/ resumo_do_projeto_satisfacao_usuarios_sus.pdf

18. Silva RVB, Stelet BP, Pinheiro R, Guizardi FL. Do elo ao laço: o agente comunitário na construção da integralidade em saúde. In: Pinheiro R, Mattos RA, organizadores. Cuidado: as fronteiras da integralidade. Rio de Janeiro (RJ): IMS/UERJ, Abrasco; São Paulo: Hucitec; 2004: 75-90.

19. Oliveira LPBA, Menezes RMP. Representações de fragilidade para idosos no contexto da estratégia saúde da família. Texto Contexto Enferm. [online]. 2011 [acesso 2010 Set 7]. 20(2). Disponível em: http:/ / www.scielo.br/scielo.php?pid=S010407072011000200012\&script=sci_arttext

20. Assis SG, Deslandes SF, Minayo MCS, Santos NC. Definição de objetivos e construção de indicadores visando a triangulação In: Minayo MCS, Assis SG, Souza ER, organizadores. Avaliação por triangulação de métodos: abordagem de programas sociais. Rio de Janeiro (RJ): Fiocruz; 2005. p. 105-33.

21. Esperidião MA, Trad LAB. Avaliação da satisfação de usuários: considerações teórico-conceituais. Cad Saúde Pública. 2006 Jun; 22(6):1267-76.

22. Diogo MJD, Ceolim MF, Cintra FA. Orientações para idosas que cuidam de idosos no domicílio. Rev Esc Enferm. USP. 2005 Mar; 39(1):97-102.

23. Gaioso LO, Mishima SM. Satisfação do usuário na perspectiva da aceitabilidade no cenário da saúde da família. Texto Contexto Enferm. 2007 Out-Dez; 16(4):617-25.

24. Veras R. Envelhecimento populacional contemporâneo: demandas, desafios e inovações. Rev Saúde Pública. 2009 Mai-Jun; 43(3):548-54. 